SHS Web of Conferences 23, 02004 (2016)

DOI: $10.1051 /$ shsconf/ 20162302004

(C) Owned by the authors, published by EDP Sciences, 2016

\title{
DOES ACCESSIBILITY TO THE CENTRAL BUSINESS DISTRICT (CBD) HAVE AN IMPACT ON HIGH-RISE CONDOMINIUM PRICE GRADIENT IN KUALA LUMPUR, MALAYSIA?
}

\author{
Mohd Faris Dziauddin \\ Mustika Misran
}

\begin{abstract}
This paper uses a spatial econometric method known as Geographically Weighted Regression (GWR) to investigate the impact of accessibility to the CBD on the high-rise condominium price gradient in Kuala Lumpur, Malaysia. Using a GWR method, after having controlled other factors, this study clearly reveal the impact of accessibility to the CBD on high-rise condominium varying prices across the study area, having a much larger positive impact in some areas but less and counterintuitive impact in others. In general, the results from this study show accessibility to the CBD measured by the travel times does affect high-rise condominium prices (high-rise condominium prices decrease as travel times to the CBD increase) in most part of the areas, hence proved Alonso, Muth and Mills were still right.
\end{abstract}

\section{INTRODUCTION}

The Central Business District (CBD) is a place where the capital's core economic activities, businesses and employment opportunities often concentrate. The CBD is also the home for a large number of households and a notable centre for culture that includes theaters, museums and cinemas. Moreover, the CBD is also regarded as the point of maximum accessibility to the city as a whole. Hence it makes the daily journeys to and from work as well as journeys to do other activities such as shopping, accessing schools and colleges, receiving healthcare and going for entertainment and recreation tend to be lower as the distance gets nearer to the CBD. All of the abovementioned positive attributes associated to the CBD have made the location closer to the CBD more attractive than location further away (urban periphery). Hence, 'the only spatial characteristic of each location in the city that matters to households is the distance from the CBD' (Fujita, 1989: p. 12). It is important to note that the attractiveness of the location is normally capitalised into land values and subsequently property values.

The standard urban economic model proposed by Alonso (1964), Muth (1969) and Mills (1972) indicates that there is a distance decay relationship between land value and distance from the CBD of a monocentric city. As a result, the greater distance a household lives from the $\mathrm{CBD}$, the more he/she will have to spend on transport costs and thus will be spending less on housing. In other words, the residential choice of the household is determined by the trade-off between space for living (housing) and accessibility to employment, which is often concentrated in the CBD. Following this reasoning, households are compensated for higher rents by reduced commuting costs (Ahlfeldt, 2007). The 
motivation for this study is that numerous early empirical studies of urban residential land or residential properties have found that the values of residential properties decrease as distance from the CBD increases (see for example, Richardson et al., 1974; McDonald, 1979; D'Ouville and McDonald, 1988).

Yet, the traditional CBD concept as previously discussed has been under substantial criticism; mostly because it is apparently no longer appropriate to describe modern urban form. Dubin and Sung (1987) argue that cities rarely have a simple monocentric structure, since employment and amenity centres are located outside of the CBD, thus may cause the rent gradient to be complex. Over the last three decades, in particular since the late 1970 s, the rapid growth of suburban nodes of economic activity and the emergence of urban sub-centres has been widely recognised. This situation can be seen in most United States of America (USA) cities where employment has been decentralised from the CBD to the suburbs as early as the 1960s (Hanson, 2004). As Heikkila et al. (1989), Garreau (1991) and Waddell et al. (1993) argue the dominance of the CBD has increasingly been challenged by the growth of suburban employment centres or in essentially exurban locations, exemplified most notably by 'edge cities'. In addition, one of the most interesting features of the modern urban landscape is the tendency of economic activity to cluster in several centres or well known as polycentric models (Anas et al., 1998).

An important question to ask is if accessibility to the CBD has an impact on high-rise condominium price gradient in Kuala Lumpur, Malaysia which has long been regarded as a monocentric city model. If it does so, to what extent the impact of accessibility to the CBD on high-rise condominium price gradient would be? The purpose of this paper therefore is to investigate the impact of accessibility to the CBD on high-rise condominium price gradient in Kuala Lumpur, Malaysia, hence could prove if Alonso, Muth and Mills were still right at least in the context of a developing country. To investigate this impact a spatial econometric method known as Geographically Weighted Regression (GWR) is employed. By employing GWR, the implicit prices ( out of own willingness ) to pay for accessibility to the CBD measured by travel times can be revealed in a spatially varying fashion.

The paper proceeds as follows. The next section reviews the prior empirical research relating to the determinants of residential property prices. The third section discusses the estimation methods used to estimate the impact of accessibility to the CBD on the high-rise condominium price gradient. This is followed by the study area and data acquisition. The fourth section discusses the data and methods employed in the empirical analysis. The fifth section details the results of the HPM and GWR methods and the final section draws conclusions and suggests avenues for future research.

\section{PRIOR EMPIRICAL FINDINGS}

As mentioned above, the CBD is a place where the capital's core economic activities, businesses and employment opportunities often concentrate. Owing to the greater concentration of economic activities, businesses and employment opportunities, studies show the price of a housing unit declines as distance to the CBD increases (see Alonso, 1964; 
Muth, 1969; Mills, 1972; Evans, 1973; Richardson et al., 1974; McDonald, 1979; D’Ouville and McDonald, 1988).

The empirical evidence also indicates that buyers have been found to value physical/structural attributes of the residential property such as floor size (Mok et al., 1995), the number of rooms, bedrooms and bathrooms (Fletcher et al., 2000), floor level (Conroy et al., 2013), building age (Clapp and Giaccotto, 1998) and garage (Forrest and Ward, 1996). In the case of condominiums, attributes such as sports and recreational facilities (tennis court, gymnasium, swimming pool and sauna), security, parking space and developer's reputation are positively valued by the buyers (Abu Zharin and Bujang, 1999).

At the same time, there is considerable empirical evidence that buyers have also been found to value a residential property located within close proximity to public transport (Mulley, 2014; Dziauddin et al., 2014; Hess and Almeida, 2006), schools (Gibbons and Machin, 2003; Mitchell, 2000), woodlands/urban forests (Powe et al., 1997; Tyrvainen, 1997), green spaces (Vandergrift and Lahr, 2011), lakes (Crompton, 2001), stadiums/sport facilities (Ahlfeldt and Kavetsos, 2014; Ahlfeldt and Maennig, 2008) and historically significant buildings (Lazrak et al., 2014). The empirical evidence also indicates that buyers prefer a residential property that is located away from noise generated by road traffic. For instance, a study carried out by Wilhelmsson (2000) in Sweden suggests that for every decibel noise generated by road traffic, the residential property price would be reduced by 0.6 per cent or a total discount of 30 per cent of the price for a residential property in a noisy location compared with a residential property located in a quiet one. Research carried out by Day et al. (2007) in Birmingham, United Kingdom (UK) and Theebe (2004) in Amsterdam, Netherlands found similar results.

Other studies also indicate that buyers are willing to pay in order to have views such as mountain (Jim and Chen, 2009) and lake (Lansford and Jones, 1995). Similarly, research has found positive view effects from location near the coast. A research carried out by Conroy and Millosch (2011) in San Diego, California, for instance, found that residential properties located within 500 feet from the coast were sold 101.6 per cent more than residential properties located further away. Research also shows that visual impacts from wind farms are valued negatively by buyers. For example, a recent investigation by Gibbons (2014) in England, UK indicated that residential properties located within two kilometres from wind farms (where the wind farms are visible) have reduced the price of residential properties of around five per cent to six per cent, falling to less than two per cent between two and four kilometres and less than one per cent by 14 kilometres.

\section{THE ESTIMATION METHODS}

To investigate the impact of accessibility to the CBD on high-rise condominium price gradient, this paper initially used a standard HPM and then moved to a spatial econometric method known as GWR.

The Hedonic Price Model (HPM) 
A good residential property that is heterogeneous can be viewed as a package of inherent attributes relevant to structural, locational and neighbourhood attributes. By regressing the transaction prices of residential properties against corresponding attributes that they possess, the contributions of these attributes to prices can be identified and estimated. The most common method used to perform this task is the HPM. This is because the HPM allows the total residential expenditure to be broken down into the values of the individual components (Sirmans and Macpherson, 2003). Studies using the HPM are too numerous to summarise in this section but Malpezzi (2002), Chin and Chou (2003) and Sirmans and Macpherson (2003) provide a broad literature overview concerning the application of the method to investigate the relationship between residential property prices and attributes.

There are two basic reasons behind the use of HPM in the residential property price study (Powe et al., 1995). First, this method is used to directly model a residential property price as a function of the levels of various attributes. Second, it is used to assume the coefficients of the estimated hedonic price function that reflects household willingness to pay (WTP) for those attributes. These coefficient values are particularly useful in deriving the marginal willingness to pay for a unit enhancement in the level of that attribute. This is achieved by evaluating the partial derivative of the hedonic price function with respect to the attribute, whilst holding all other variables at their mean values. The general form of a HPM could be represented as follows:

$$
\mathrm{P}_{\mathrm{i}}=f(\mathrm{~F}, \mathrm{~S}, \mathrm{~L})+\varepsilon_{\mathrm{i}}
$$

where $\mathrm{P}_{\mathrm{i}}$ is the sale price of residential property $\mathrm{i}, \mathrm{F}$ is a vector of focus variable (in this case is accessibility to the CBD measured by car travel time in minute), $\mathrm{S}$ is a vector of structural variables such as floor size and number of bedrooms, $L$ is a vector of locational variables such as housing sub-markets, and $\varepsilon_{\mathrm{i}}$ is a vector of random error terms.

\section{Geographically Weighted Regression (GWR) Approach}

Since it was first emerged in the econometric literature, HPM has been used extensively to construct house price indices (Can and Megbolugbe, 1997; Mills and Simenauer, 1996) and investigate household demand for residential property attributes that include among others, school quality (Mitchell, 2000), public transport (Hess and Almeida, 2007), woodland/urban forest (Powe et al., 1997; Tyrvainen, 1997), golf courses (Do and Grunditski, 1995), environmental quality (Jim and Chen, 2009; Lansford and Jones, 1995) and sports arenas (Ahlfeldt and Maennig, 2010; Tu, 2005).

However, as widely recognised, one of the limitations of the HPM is its insensitivity to deal with the existence of spatial effects in residential property prices-attributes relationships. For example, in HPM the relationship between residential property prices and attributes is assumed to be stationary over geographical space. Anselin (1988) argues that the presence of spatial effects on the validity of traditional statistical methods has long been recognised as a potential problem. Fotheringham et al. (2002) acknowledged that the relationship between residential property prices and attributes across geographical space in stationary fashion may not be representative of the situation in any particular part of the study 
area and may hide some very interesting and important local differences in the determinants of residential property prices. This is due to the fact that the data used in HPM are spatial in nature because they are based on residential property sales in a given area.

It is worth highlighting that failure to consider the spatial effects results in inefficient coefficient estimates. The GWR approach on the other hand has the capability in dealing with spatial effects, that is, by "calibrating a multiple regression model which allows different relationships to exist at different point in space" (Brunsdon et al., 1996: p. 1) in which observations located closer are weighted more than observations located further away. GWR was introduced to the geographical and spatial econometric literature by Brunsdon et al. in 1996, formalised by Fotheringham et al. in 2002, later by Charlton and Fotheringham (2009) and extended by Nakaya et al. (2009). This technique subsequently has received considerable attention in recent years to model spatially varying relationships between dependent and an explanatory variables in real estate and various other fields including ecology (for example, Wang et al., 2005), urban structure (for example, Luo and Wei, 2009; Mohd Shariff and Rainis, 2009), land use change (for example, Hanham et al., 2009; Wang et al., 2011) and political geography (for example, Calvo and Escolar, 2003). However, since this paper focuses on real estate, the discussion in this section will be concentrating on the applications of GWR technique in the relevant research areas. Also, whilst this paper is focuses on GWR, it is important to recognise some studies that have applied other spatial econometric methods such as spatial expansion method and multilevel modelling in order to study residential property prices-attributes relationships (for example, Jones and Bullen, 1993; Orford, 1999).

In the real estate research, a number of studies have attempted to take advantage of GWR technique to investigate and appropriately modeled household demand for residential property attributes whether in general (for example, Lehner, 2011; McCord et al., 2012; Crespo and Grêt-Regamey, 2013) or specific terms such as public transport (for example, Du and Mulley, 2006; Banister, 2007; Dziauddin et al., 2015), road improvement (for example, Mulley, 2013), parks (for example, McMullen, 2011), environmental quality (for example, Carruthers and Clark, 2009) and neighbourhood quality (for example, Sunak and Madlener, 2012). In all of these studies, the authors report GWR performed better than OLS as indicated by a higher adjusted $\mathrm{R}^{2}$, a lower AIC and large differences in parameter estimates. Most importantly they have demonstrated that residential property price premiums are varied in terms of the effect and magnitude across geographical space. In other words, the empirical evidence provided by these studies has supported the presence of spatial heterogeneity across geographical space which is unable to be identified by the HPM. For example, in a study on the effect of rail transit systems on residential property prices, Du and Mulley (2006), Banister (2007) and Dziauddin et al. (2015) used GWR to investigate household demand for the commuting service provided by rail transit systems in north-east of England, United Kingdom (UK), London, UK and Greater Kuala Lumpur, Malaysia respectively. In these studies, the authors report not only large differences in parameter estimates between GWR and OLS, but they also demonstrate that these parameter estimates varied across geographical space. Furthermore, they successfully identify on how local factors such as the desirability of the area, income characteristics of the neighbourhoods, unemployment rate, quality of the pre-existing transport systems, negative effects of poor parking facilities at stations and 
accessibility improvement to the CBD and local schools influenced household's marginal willingness to pay for the service provided by the rail transit systems. They have concluded that these spatially varying relationships across geographical space are completely unseen in the HPM. Meanwhile, in a study on the effect of a new-build transit way for buses in a suburban area of south-west Sydney, Australia on residential property prices, Mulley (2014) has arrived at similar conclusion where she concluded that GWR provides the opportunity to observe spatial variability in residential property price premiums across geographical space due to the improvement in accessibility to shopping mall and employment facilities provided by a new-build transit way for buses, thus can assist policy makers in identifying the best approach to implement land value capture policy as a funding mechanism for bus-related infrastructure investments.

Since HPM provides a basis for GWR, by including longitude and latitude coordinates $\left(\mathrm{u}_{\mathrm{i}}, \mathrm{v}_{\mathrm{i}}\right)$ to the equation (1) above, the general form of a HPM can be mathematically expressed at location $i$ in space as follows (Crespo and Grêt-Regamey, 2013: p. 667):

$$
\begin{array}{ll}
\mathrm{P}_{\mathrm{i}}\left(\mathrm{u}_{\mathrm{i}}, \mathrm{v}_{\mathrm{i}}\right)=\beta_{0}\left(\mathrm{u}_{\mathrm{i}}, \mathrm{v}_{\mathrm{i}}\right)+\sum_{\mathrm{k}=1}^{\mathrm{p}} \beta_{\mathrm{k}}\left(\mathrm{u}_{\mathrm{i}}, \mathrm{v}_{\mathrm{i}}\right) x_{\mathrm{ik}}+\varepsilon_{\mathrm{i}}, \quad i=1, \ldots, \mathrm{n}, \\
\text { where, } \\
\begin{array}{ll}
\mathrm{P}_{\mathrm{i}} & \text { the response variable at point } i, \\
\mathrm{u}_{\mathrm{i}}, \mathrm{v}_{\mathrm{i}} & =\text { the spatial coordinates of point } i, \\
\beta_{0}\left(\mathrm{u}_{\mathrm{i}}, \mathrm{v}_{\mathrm{i}}\right) & =\text { the location-specific intercept term parameter, } \\
\beta_{\mathrm{k}}\left(\mathrm{u}_{\mathrm{i}}, \mathrm{v}_{\mathrm{i}}\right) & =\text { the } k \text { th location-specific parameter, } \\
\mathrm{p} & =\text { the number of unknown local parameters to be estimated } \\
& (\text { excluding the intercept term), } \\
x_{\mathrm{ik}} & \text { the } k \text { th explanatory variable associated with } \beta_{\mathrm{k}}, \\
\varepsilon_{\mathrm{i}} & =\text { a random component assumed to be independently and } \\
\mathrm{n} & \text { identically distributed, } \\
= & \text { the number of observations }
\end{array}
\end{array}
$$

Based on equation 2 above, location-specific parameters $\beta_{k}\left(u_{i}, v_{i}\right)$ are estimated using weighted least squares and can be expressed as follows (Crespo and Grêt-Regamey, 2013: p. 667-668):

$$
\begin{array}{ll}
\hat{\beta}\left(\mathrm{u}_{\mathrm{i}}, \mathrm{v}_{\mathrm{i}}\right)=\left[\mathrm{X}^{\mathrm{T}} \mathrm{W}_{\mathrm{i}} \mathrm{X}\right]^{-1} \mathrm{X}^{\mathrm{T}} \mathrm{W}_{\mathrm{ip}}, \quad i=1, \ldots, \mathrm{n}, \\
\begin{array}{ll}
\text { where, } \\
\hat{\beta}\left(\mathrm{u}_{\mathrm{i}}, \mathrm{v}_{\mathrm{i}}\right) & =\mathrm{a}(p \times 1) \text { vector parameter estimates at location } i, \\
\mathrm{X} & =\text { an }(n \times p) \text { matrix of observed explanatory variables, } \\
\mathrm{W}_{\mathrm{i}} & =\mathrm{a} \text { distance decay }(n \times n) \text { matrix } \\
\mathrm{p} & =\text { an }(n \times 1) \text { vector of observed response variables, }
\end{array}
\end{array}
$$


Note that $p$ and $i$ are as defined in the equation 2 above. Location $i$ is also denoted as the regression point; the point at which parameters are being estimated. As expressed in the equation above, the weighting of an observation is done through a distance decay matrix $\left(W_{i}\right)$ so that observations located near to the point in space are weighted more than observations located further away. By this geographically weighted calibration, continuous and smooth surfaces of local parameter estimates can be mapped over the geographical area. The advantage of using GWR in comparison to other spatial methods such as multilevel modelling is that each observation is treated as an individual observation at a specific geographic point. Thus, the maps produced will not be limited within an artificially bounded geographical area such as political or administrative boundaries as normally required when modelling spatial data (Du and Mulley, 2012; Crespo and Grêt-Regamey, 2013).

\section{THE STUDY AREA AND DATA ACQUISITION}

\section{The Study Area}

The study area covers the whole of Kuala Lumpur, the capital city of Malaysia. Kuala Lumpur is not only the capital city of Malaysia, but also one of Asia's most iconic cities, a major financial and commercial centre and home to hundreds of multinational companies. In addition to being one of Asia's most iconic cities, Kuala Lumpur has a stable and attractive business environment, a burgeoning middle-class population, quality infrastructure and a skilled workforce. From 982,920 people in 1980, the population of Kuala Lumpur has risen to 1.58 million people as of in 2010 (Department of Statistics Malaysia, 2010; 1980) and encompasses a total land area of 243 square kilometres - this has made Kuala Lumpur a densely populated city in Malaysia. Whilst Kuala Lumpur is host to 1.58 million permanent residents, the city's total population swells to more than 2.5 million people during the day as workers predominantly from the surrounding areas travel to the city for work. Kuala Lumpur is made up of 41 per cent ethnic Malays, 39 per cent ethnic Chinese, 9 per cent ethnic Indians, 1.6 per cent is a mix of other ethnicities and the rest are Non-Malaysian citizens (Department of Statistics Malaysia, 2010).

From a small tin-mining town founded over 150 years ago, today Kuala Lumpur has developed and expended into Greater Kuala Lumpur - the term advocated by Malaysian Prime Minister Najib Razak as an urban agglomeration to spur the country's economic growth by the billions in the Economic Transformation Programme (ETP) launched in 2010. Greater Kuala Lumpur is defined as an area covered by 10 municipalities surrounding Kuala Lumpur Metropolitan Area with land area of 2,793.27 square kilometres. From earning a GDP per capita at purchasing power parity (PPP) of MYR7,497 (USD2,998) in 1980, the GDP per capita at PPP of Kuala Lumpur has mounted to MYR55,951 (USD18,218) in 2010 (Yearbook Statistics of Malaysia, 2010; 1984).

The development of Kuala Lumpur has taken the form of a concentration economic activity in the centre, with ribbon developments along the major arterials leading into the city. As of 2003, the percentage of employment located in the CBD is relatively high namely at 24 per cent. This percentage, however, has reduced to 12 per cent in 2010; generally due to the 
emergence of several sub-centres near major road intersections. In addition, there are also an increasing number of private vehicles-oriented economic and commercial activities such as business parks and shopping malls located away from the CBD, mostly near the expressways. It is the policy of Malaysian government as clearly stated in the Kuala Lumpur Structure Plan crafted in 1984 to disperse urban development which primarily concentrated in Kuala Lumpur's CBD to the city as a whole and sub-urban area. But, it is important to highlight that although there have been dispersal trends of economic activities, businesses and employment opportunities, the CBD continues to be by far the most dominant and important location in Kuala Lumpur.

\section{Data Acquisation}

Residential property data Residential property price transaction data used in this study come from the sale of condominium units in Kuala Lumpur market for 2010. In total, 5,639 units of condominium selling prices, together with their structural attributes, were collected across 26 sub-markets in the area. These data were collected from the Department of Valuation and Services, Malaysia (Kuala Lumpur branch). The structural attributes of the condominium units obtained from the data provider and used for the analysis are ownership status of the condominium units, floor size and number of bedrooms.

Real estate professionals involved in residential property market in Kuala Lumpur have generally classified residential property sub-markets in the area into 26 (see Figure 1). From these 26 sub-markets, 10 of them are generally perceived as the "Prime" areas. These 10 prime areas are Kuala Lumpur city centre (KLCC), Bukit Bintang, Kampung Attap, Kuala Lumpur Sentral (KL Sentral), Bangsar, Bukit Damansara, Taman Tun Dr. Ismail (TTDI), Bukit Tunku, Dutamas and Mon't Kiara.

It is worth mentioning that these 10 prime areas are home for major landmarks such as PETRONAS Twin Towers (located in KLCC), Malaysia's most famous department stores such as Suria KLCC Mall (located in KLCC), Pavillion, Lot 10 and Star Hill (located in Bukit Bintang), residence of Malaysia's royal families, ministers, middle and upper class families, and expatriates (located in KLCC, Bangsar, Dutamas, Mon't Kiara, KL Sentral, Bukit Damansara, Taman Tun Dr. Ismail and Bukit Tunku). Due to the reputation that they have as described above, we anticipate that these prime areas will contribute not only positively but with better premium to the high-rise condominium prices. 


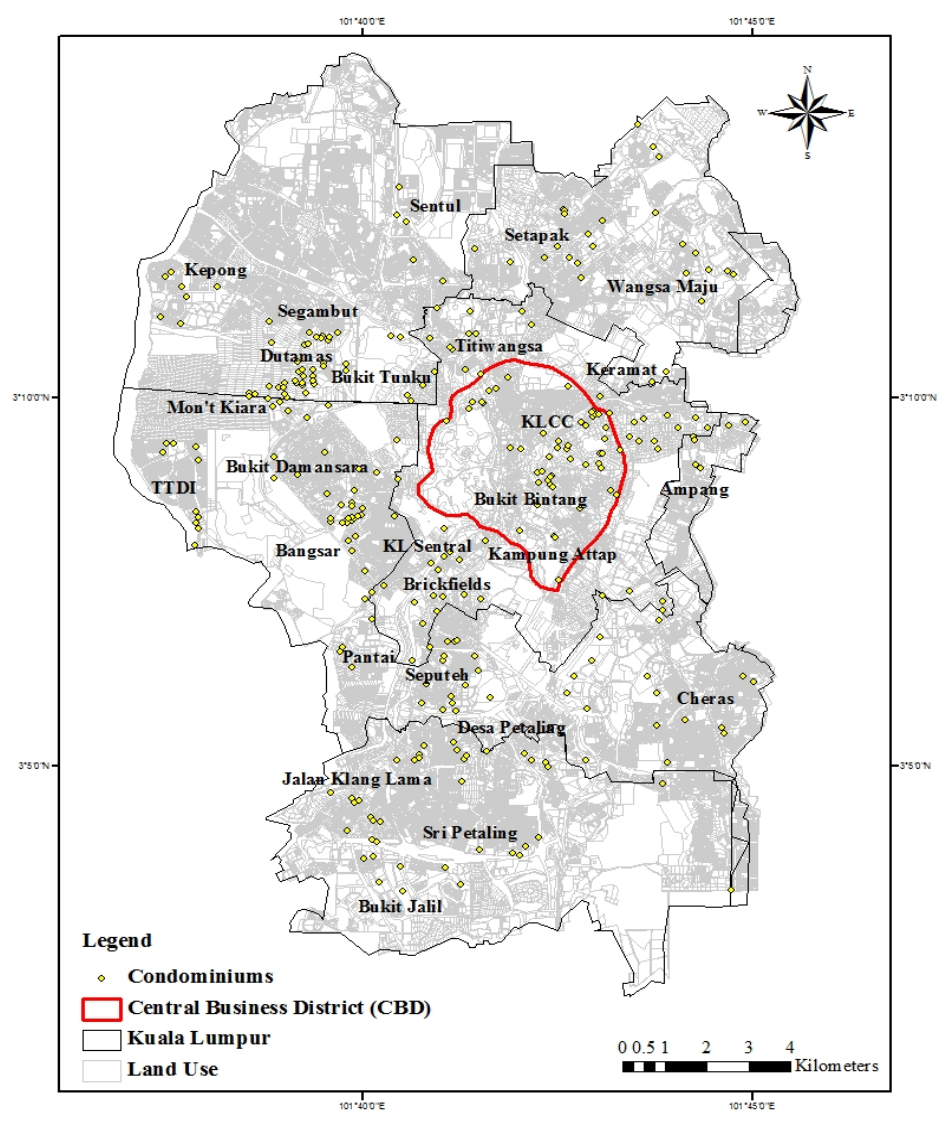

Figure 1: Map of Kuala Lumpur, housing sub-markets and condominiums distribution

Table 1 shows the characteristics of the data set for the condominium units within the 26 submarkets in Kuala Lumpur. Out of the total sample, 45.85 per cent is recorded in prime areas housing sub-markets; of these, 16.29 per cent are units sold from Mon't Kiara housing submarket. The fewest of sales is recorded in Pantai housing sub-market ( 0.25 per cent). The average sales price are ranging from slightly more than MYR $\$ 200,000$ to over MYR $\$ 1$ million. Of these, at least three housing sub-markets are recorded average sales price over MYR \$1 million; Bangsar, Bukit Tunku and KLCC housing sub-markets. Comparing this sample to other locations in Malaysia such as Georgetown in Penang and Johor Bahru in Johor, the average price of condominiums in Kuala Lumpur is considered expensive even for middle-class Malaysians.

Distance and Travel Time to the CBD Data In order to measure the distance for a given condominium to the CBD, a geographical information system (GIS) was used. For this GIS was used to position each observation (condominium buildings) accurately on a local map by 
using geographical coordinates (latitude and longitude) obtained from Google Maps. GIS and spatial analysis were also integrated in this study and the integration has been particularly useful because the proximity from observations to the CBD was measured accurately using network distance. The distance in metres was measured along the street network by using a GIS programme named Multiple Origins to Multiple Destinations, obtained from the Environmental Systems Research Institute (ESRI) support centre ${ }^{1}$. The network-distance measurement using this programme requires three layers of spatial data; points of origin (observations), points of destinations (CBD attribute) and the road network data. This allowed the shortest route from each observation to the CBD to be calculated. Moreover, the Multiple Origins to Multiple Destinations programme allows more than one destination to be selected at any one time. Thus, proximity to the CBD can be calculated simultaneously for each observation.

Table 1: Characteristics of condominium units by housing sub-markets

\begin{tabular}{|c|c|c|c|}
\hline Sub-market & $\begin{array}{r}\text { Units } \\
\text { sold } \\
\end{array}$ & $\begin{array}{r}\text { Percentage } \\
(\%)\end{array}$ & $\begin{array}{r}\text { Average sales } \\
\text { price (MYR) }\end{array}$ \\
\hline Ampang & 149 & 2.64 & 848,767 \\
\hline Bangsar & 277 & 4.91 & $1,033,882$ \\
\hline Brickfields & 60 & 1.06 & 384,752 \\
\hline Bukit Bintang & 102 & 1.81 & 442,403 \\
\hline Bukit Damansara & 79 & 1.40 & 818,422 \\
\hline Bukit Jalil & 312 & 5.53 & 273,414 \\
\hline Bukit Tunku & 51 & 0.90 & $1,171,971$ \\
\hline Cheras & 273 & 4.84 & 216,815 \\
\hline Desa Petaling & 80 & 1.42 & 174,936 \\
\hline Dutamas & 350 & 6.21 & 339,284 \\
\hline Jalan Klang Lama & 546 & 9.68 & 216,782 \\
\hline Kampung Attap & 124 & 2.19 & 333,966 \\
\hline Kepong & 152 & 2.69 & 520,060 \\
\hline Keramat & 54 & 0.96 & 254,796 \\
\hline KL Sentral & 166 & 2.94 & 834,214 \\
\hline KLCC & 233 & 4.13 & $1,352,518$ \\
\hline Mon't Kiara & 919 & 16.29 & 897,932 \\
\hline Pantai & 14 & 0.25 & 280,964 \\
\hline Segambut & 54 & 0.96 & 323,176 \\
\hline Sentul & 561 & 9.96 & 307,460 \\
\hline Seputeh & 197 & 3.49 & 375,565 \\
\hline Setapak & 297 & 5.28 & 255,099 \\
\hline Sri Petaling & 196 & 3.48 & 184,167 \\
\hline Taman Tun Dr Ismail & 137 & 2.43 & 552,551 \\
\hline Titiwangsa & 74 & 1.32 & 351,122 \\
\hline
\end{tabular}




\begin{tabular}{lrrr} 
Wangsa Maju & 182 & 3.23 & 383,292 \\
\hline Total & 5639 & 100.00 & 525,853 \\
\hline
\end{tabular}

The travel time to the CBD variable (TIMECBD) was calculated by taking into account several factors namely, regular roads to the CBD for each observation and speed limits. The times that people take to travel to and from the CBD in the morning and evening were chosen since these are the two time periods which have been identified as peak periods during the day where people travel to and from work. As for regular roads to the CBD, the choice is based on the data obtained from the extensive study conducted by the Geography Department at University of Malaya and Google Maps. Regarding speed limits, it is important to consider barriers caused by serious traffic congestion to the CBD during peak periods. The speed limits for each road in this study were obtained from studies conducted by Mohammad and Kiggundu (2007) and the Ministry of Transports, Malaysia. Finally, the travel time by car to the CBD were obtained, and was then used as the focus variable in the principle analysis. It has to be noted, however, that travel times to the CBD were chosen because they provide better measures of location and accessibility to the CBD than simple distances and the significant results of previous studies (see, for example, Dziauddin et al., 2015; Ottensman et al., 2008).

A list of explanatory variables considered for inclusion in the HPM together with their descriptive statistics is given in Table 2. For the travel time to the CBD variable, the average travel time from observations to the $\mathrm{CBD}$ is around 19 minutes. But, there are observations with as short as three minutes to as long as 41 minutes of travel time to the CBD. As of in Table 1, similar variation could also be observed in the characteristics of the individual condominiums presented in Table 2. From the sample, condominium sales prices are ranging from MYR $\$ 100,000$ to over MYR $\$ 7$ million. In terms of the floor size, the average condominium has a floor area of around 130 square metre or 1300 square feet. However, there are units with as few as 60 square metre or 600 square feet to as many as 930 square metre or 9300 square feet. 


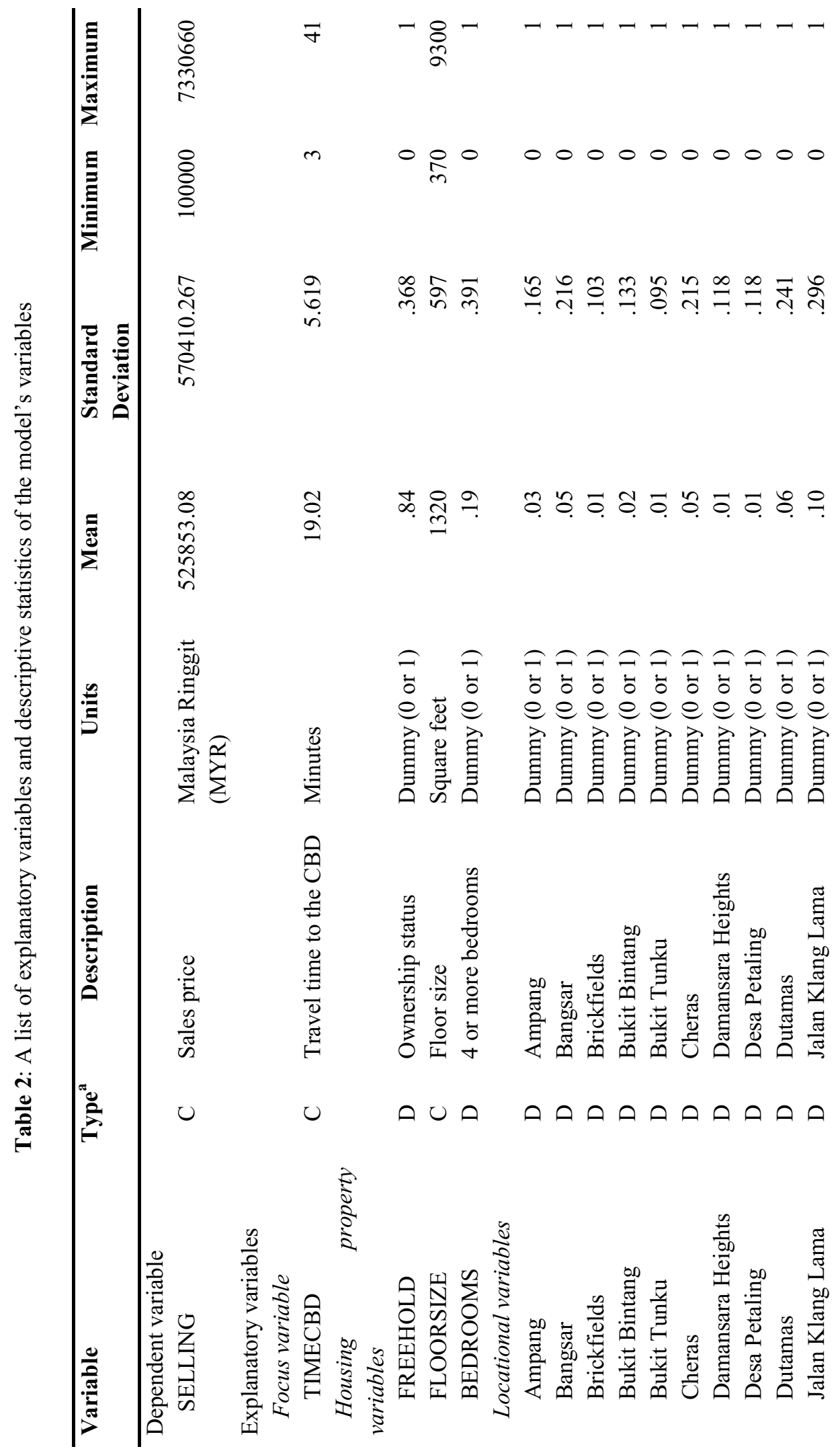


PSU-USM-NSTRU 2014

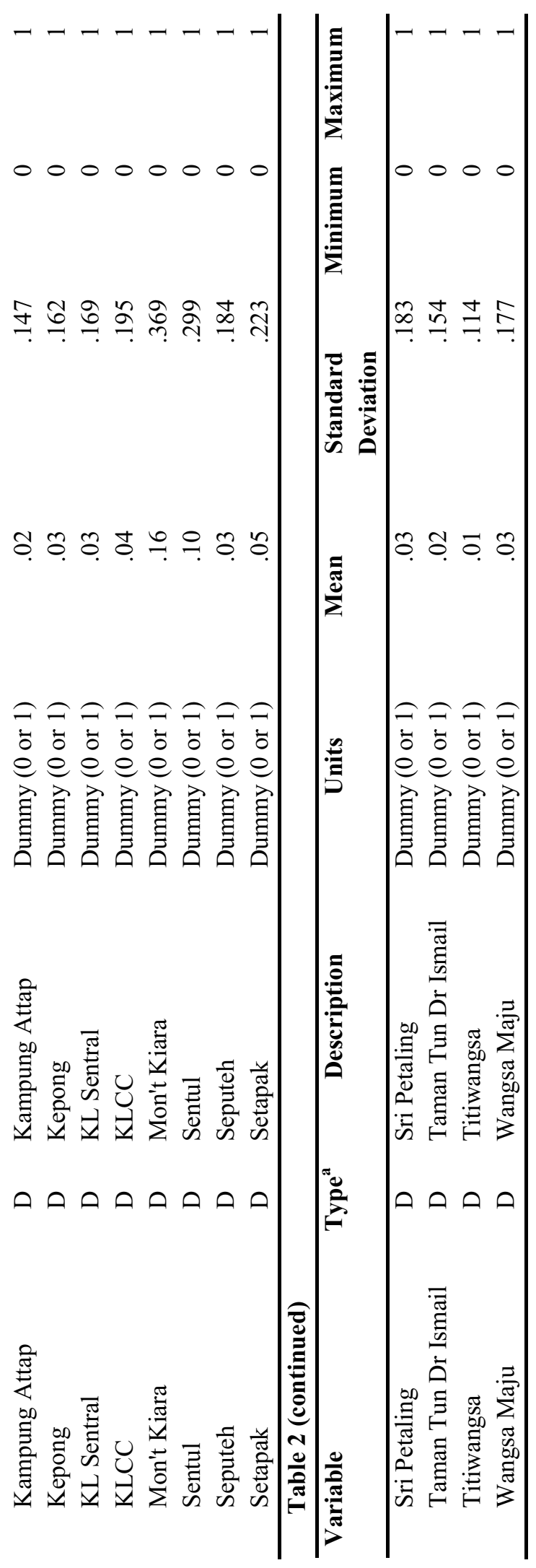


Besides focus and structural variables, dummy locational variables for each of housing sub-markets stated above were also included for the principal analysis. It is worth highlighting that in all regression-based analysis some explanatory variables are often multicollinear. To handle this problem, the correlations among the explanatory variables used for the inclusion in the final models were detected by employing Pearson's correlation coefficient and variance inflation factors (VIF). Following Orford (1999), a Pearson's correlation coefficient above 0.8 and a VIF above ten indicate harmful collinearity. This rule was applied within this study.

\section{EMPIRICAL RESULTS}

The results of the HPM and GWR models are shown below in two stages: the first part shows the results from the HPM and the second part shows the results from GWR model.

\section{The HPM Estimation}

Following seminal work in the area of hedonic pricing by Rosen (1974), Freeman (1979b) Halvorsen and Pollawski (1981) and Palmquist (1984), there were four common functional forms used to measure the relationship between dependent and the explanatory variables in HPM: standard OLS hedonic price function, semi-log, double-log and Box-Cox transformations. Unfortunately, there is no theoretical motivation on how to choose a particular functional form in HPM except with the work of Cropper et al. (1988) - they have reviewed extensively the choice of functional form for HPM by previous researchers and they concluded that linear, semi-log, double-log and Box-Cox linear perform best with quadratic forms, including the quadratic BoxCox, faring relatively badly. After performing and comparing these functional forms for the data in this study, we found that semi-log functional form performed better, thus employed to estimate the impact of accessibility to the CBD on high-rise condominium price gradient in this study. Note that semi-log functional form has some advantages over other functional forms where the coefficients are easy to interpret 'as the percentage change in the price given a oneunit change in the attributes, a semi-log specification allows for variation in the dollar value of each attributes and the semi-log model helps minimize the problem of heteroscedasticity' (Sirmans and Macpherson, 2003: p. 5). The semi-log regression equation is regressed on a set of determinants as follows:

$\operatorname{lnP}_{\mathrm{i}}=\beta_{0}+\beta_{1}$ TIMECBD $_{\mathrm{i}}+\beta_{2}$ FREEHOLD $_{\mathrm{i}}+\beta_{3}$ FLOORSIZE $_{\mathrm{i}}+\beta_{4}$ BEDROOMS $_{\mathrm{i}}+\beta_{5}$ Ampang $_{\mathrm{i}}+$

$\beta_{6}$ BandarKualaLumpur $_{\mathrm{i}}+\beta_{7}$ KualaLumpur $_{\mathrm{i}}+\beta_{8}$ Batu $_{\mathrm{i}}+\beta_{9}$ Petaling $_{\mathrm{i}}+\beta_{10}$ Setapak $_{\mathrm{i}}+$
$\beta_{11}$ DamansaraHeights $_{\mathrm{i}}+\beta_{12}$ DesaPetaling $_{\mathrm{i}}+\beta_{13}$ Dutamas $_{\mathrm{i}}+\beta_{14}$ JalanKlangLama $_{\mathrm{i}}+$
$\beta_{15}$ Kepong $_{\mathrm{i}}+\beta_{16}$ KLSentral $_{\mathrm{i}}+\beta_{17}$ KLCC $_{\mathrm{i}}+\beta_{18}$ MontKiara $_{\mathrm{i}}+\beta_{19}$ Sentul $_{\mathrm{i}}+\beta_{20}$ Seputeh $_{\mathrm{i}}+$
$\beta_{21}$ SriPetaling $_{\mathrm{i}}+\beta_{22}$ TamanTunDrIsmail $_{\mathrm{i}}+\beta_{23}$ Titiwangsa $_{\mathrm{i}}+\beta_{23}$ WangsaMaju $_{\mathrm{i}}+\varepsilon_{\mathrm{i}}$ (4) 
where $i$ is the subscript denoting each property and $\ln \mathrm{P}_{\mathrm{i}}$ is the price of property $i$ in Malaysian Ringgit (MYR) with natural logarithm transformation. TIMECBD is the travel time to the CBD measured in minutes. Structural attributes of the condominium unit variables include freehold status (FREEHOLD) of the property, size of the floor (FLOORSIZE) measured in square feet and property with four or more bedrooms (BEDROOMS). Ampang, Bangsar, Briekfields, Bukit Bintang, Bukit Tunku, Cheras, Damansara Heights, Desa Petaling, Dutamas, Jalan Klang Lama, Kepong, KL Sentral, KLCC, Mont Kiara, Sentul, Seputeh, Sri Petaling, Taman Tun Dr. Ismail, Titiwangsa and Wangsa Maju are a set of dummy locational variables that illustrate housing submarkets.

Table 3 presents the summary of the estimated coefficients for semi-log regression specification. In general, the model explains approximately $81 \%$ of the variation in the dependent variable. This is on par with other published empirical results. Within the final model, all of the explanatory variables that influenced high-rise condominium price were significant at the $1 \%$ level and have the anticipated positive and negative signs.

Table 3: Summary statistics for semi-log regression estimation $(n=5639)$

\begin{tabular}{|c|c|c|c|c|c|c|c|}
\hline \multirow[t]{2}{*}{ Variable } & \multicolumn{2}{|c|}{$\begin{array}{c}\text { Unstandardized } \\
\text { Coefficients } \\
\end{array}$} & \multirow{2}{*}{$\begin{array}{r}\begin{array}{c}\text { Standardized } \\
\text { Coefficients }\end{array} \\
\text { Beta }\end{array}$} & \multirow[b]{2}{*}{ t-value } & \multirow[b]{2}{*}{ Sig. } & \multicolumn{2}{|c|}{$\begin{array}{c}\text { Collinearity } \\
\text { Statistics } \\
\end{array}$} \\
\hline & $\mathrm{B}$ & $\begin{array}{l}\text { Std. } \\
\text { error }\end{array}$ & & & & Tolerence & VIF \\
\hline (Constant) & 11.779 & .030 & & 386.357 & & & \\
\hline TIMECBD & -.007 & .001 & -.058 & -6.492 & .000 & .403 & 2.484 \\
\hline FREEHOLD & .126 & .014 & .064 & 8.855 & .000 & .609 & 1.642 \\
\hline FLOORSIZE & .001 & .000 & .502 & 72.508 & .000 & .660 & 1.515 \\
\hline BEDROOMS & .157 & .012 & .084 & 12.773 & .000 & .722 & 1.385 \\
\hline Ampang & .613 & .030 & .136 & 20.631 & .000 & .729 & 1.371 \\
\hline Bangsar & .781 & .023 & .233 & 34.004 & .000 & .676 & 1.479 \\
\hline Brickfields & .285 & .042 & .040 & 6.831 & .000 & .909 & 1.100 \\
\hline Bukit Bintang & .354 & .035 & .065 & 10.125 & .000 & .765 & 1.306 \\
\hline Bukit Tunku & .771 & .045 & .101 & 16.977 & .000 & .898 & 1.114 \\
\hline Cheras & -.097 & .024 & -.029 & -4.037 & .000 & .624 & 1.604 \\
\hline Damansara Heights & .800 & .037 & .130 & 21.717 & .000 & .883 & 1.132 \\
\hline Desa Petaling & -.225 & .038 & -.037 & -5.902 & .000 & .817 & 1.224 \\
\hline Dutamas & .132 & .021 & .044 & 6.266 & .000 & .638 & 1.568 \\
\hline Jalan Klang Lama & -.147 & .020 & -.060 & -7.398 & .000 & .479 & 2.088 \\
\hline Kepong & .526 & .029 & .118 & 17.827 & .000 & .726 & 1.377 \\
\hline KL Sentral & .921 & .027 & .215 & 33.761 & .000 & .780 & 1.283 \\
\hline
\end{tabular}




\begin{tabular}{lrrrrrrr}
\hline KLCC & .796 & .028 & .219 & 28.760 & .000 & .546 & 1.830 \\
Mon't Kiara & .678 & .017 & .346 & 39.585 & .000 & .414 & 2.412 \\
Sentul & .104 & .019 & .043 & 5.538 & .000 & .524 & 1.908 \\
Seputeh & .235 & .026 & .059 & 9.186 & .000 & .753 & 1.327 \\
Setapak & -.105 & .022 & -.032 & -4.696 & .000 & .670 & 1.492 \\
Sri Petaling & -.114 & .030 & -.029 & -3.808 & .000 & .549 & 1.825 \\
Taman Tun Dr Ismail & .468 & .029 & .099 & 15.927 & .000 & .808 & 1.237 \\
Titiwangsa & .161 & .038 & .025 & 4.179 & .000 & .867 & 1.153 \\
Wangsa Maju & .228 & .027 & .056 & 8.325 & .000 & .706 & 1.417 \\
\hline
\end{tabular}

Notes: Goodness of fit: Adjusted $\mathrm{R}^{2}=0.81$

As this is a semi-log functional form, the interpretation of the estimated coefficients relates to their proportional (or when multiplied by 100, the percentage) effect on Price. Results presented in Table 3 indicate that 10 minutes increases in travel times to the CBD are associated with 7 per cent decline in sales price indicating strong evidence of the existence of a price gradient from the CBD. As expected, the coefficients for freehold status (FREEHOLD), size of floor area (FLOORSIZE) and a unit of condominium with four or more bedrooms (BEDROOMS) are positive and significant. Specifically, a unit of condominium with freehold status is associated with 12.6 per cent increase in sales price, for every square feet increase in floor size with a 0.7 per cent increase and a unit of condominium with four or more bedrooms with a 15.7 per cent increase. Finally, most of the housing sub-market dummies are positive and significant. It is worth highlighting that the "Prime" housing sub-market areas have the largest positive "housing sub-market effect" in sales price.

\section{Calibration of the HPM: GWR Estimation}

Table 3 above presents the summary of the estimated coefficients obtained from the HPM in a single value whilst the estimated coefficients from GWR are shown in multiple values (mean, standard deviation, minimum, maximum, range, lower quartile, median, and upper quartile). It is clear that the values of estimated coefficients are not homogenous but vary for all of explanatory variables. The summary results of GWR in Table 4 also indicate that the GWR is performed better than the HPM since adjusted $\mathrm{R}^{2}$ has improved from $81 \%$ to $84 \%$ in explaining the variation in the dependent variable and a lower Akaike Information Criterion (AIC) (from 3017.74 down to 2074.746). More importantly, the GWR is able to explore the spatial variation of explanatory variables in the model, where the coefficients of explanatory variables may vary significantly over geographical space. 
Table 4: Summary statistics for varying (local) coefficients $(n=5639)$

\begin{tabular}{|c|c|c|c|c|c|c|c|c|}
\hline Variable & $\begin{array}{l}\text { Coeff. } \\
\text { Mean }\end{array}$ & $\begin{array}{l}\text { Coeff. } \\
\text { S.D. }\end{array}$ & $\begin{array}{c}\text { Coeff. } \\
\text { Min }\end{array}$ & $\begin{array}{l}\text { Coeff. } \\
\text { Max }\end{array}$ & $\begin{array}{l}\text { Coeff. } \\
\text { Range }\end{array}$ & $\begin{array}{c}\text { Coeff. } \\
\text { Lower } \\
\text { quartile }\end{array}$ & $\begin{array}{c}\text { Coeff. } \\
\text { Median }\end{array}$ & $\begin{array}{c}\text { Coeff. } \\
\text { Upper } \\
\text { quartile }\end{array}$ \\
\hline (Constant) & 11.6472 & 0.3906 & 10.2973 & 12.1068 & 1.8094 & 11.5878 & 11.7620 & 11.9004 \\
\hline TIMECBD & -0.0098 & 0.0129 & -0.0343 & 0.0239 & 0.0582 & -0.0193 & -0.0129 & -0.0036 \\
\hline FREEHOLD & 0.2698 & 0.2799 & 0.0081 & 1.0843 & 1.0763 & 0.0527 & 0.1426 & 0.4427 \\
\hline FLOORSIZE & 0.0006 & 0.0001 & 0.0005 & 0.0008 & 0.0003 & 0.0005 & 0.0006 & 0.0006 \\
\hline BEDROOMS & 0.2081 & 0.1046 & 0.0052 & 0.5093 & 0.5041 & 0.1598 & 0.2041 & 0.2416 \\
\hline Ampang & 0.6782 & 0.1921 & 0.2896 & 1.3294 & 1.0398 & 0.5948 & 0.6271 & 0.6831 \\
\hline Bangsar & 0.8272 & 0.1223 & 0.6218 & 1.1699 & 0.5482 & 0.7296 & 0.7871 & 0.9401 \\
\hline Brickfields & 0.2876 & 0.0506 & 0.1894 & 0.4205 & 0.2311 & 0.2440 & 0.2869 & 0.3285 \\
\hline Bukit Bintang & 0.4284 & 0.2016 & 0.1252 & 1.1773 & 1.0522 & 0.3121 & 0.3832 & 0.4656 \\
\hline Bukit Tunku & 0.7434 & 0.1037 & 0.4503 & 0.9829 & 0.5326 & 0.6832 & 0.7471 & 0.8151 \\
\hline Cheras & -0.1184 & 0.0551 & -0.2518 & 0.0359 & 0.2878 & -0.1548 & -0.1106 & -0.0892 \\
\hline Damansara Heights & 0.7896 & 0.1243 & 0.4767 & 1.0551 & 0.5783 & 0.7335 & 0.7750 & 0.8564 \\
\hline Desa Petaling & -0.1410 & 0.2040 & -0.5155 & 0.4767 & 0.9922 & -0.2759 & -0.2320 & -0.0265 \\
\hline Dutamas & 0.1437 & 0.0527 & 0.0018 & 0.2659 & 0.2642 & 0.1204 & 0.1464 & 0.1719 \\
\hline Jalan Klang Lama & 0.0909 & 0.2057 & -0.2120 & 0.4915 & 0.7035 & -0.1017 & 0.0662 & 0.2866 \\
\hline Kepong & 0.5271 & 0.1605 & 0.1408 & 0.8220 & 0.6812 & 0.3795 & 0.5545 & 0.6618 \\
\hline KL Sentral & 0.9036 & 0.0684 & 0.7427 & 1.0797 & 0.3369 & 0.8524 & 0.9079 & 0.9554 \\
\hline KLCC & 0.7309 & 0.1595 & 0.4875 & 1.2545 & 0.7669 & 0.6343 & 0.7029 & 0.7704 \\
\hline Mon't Kiara & 0.6462 & 0.0700 & 0.4958 & 0.7882 & 0.2923 & 0.5858 & 0.6554 & 0.7062 \\
\hline Sentul & 0.2769 & 0.1952 & -0.0434 & 0.8405 & 0.8839 & 0.1639 & 0.2346 & 0.3312 \\
\hline Seputeh & 0.2802 & 0.0872 & 0.0954 & 0.4693 & 0.3739 & 0.2193 & 0.2779 & 0.3492 \\
\hline Setapak & -0.0244 & 0.2678 & -0.3537 & 0.6244 & 0.9781 & -0.2024 & -0.1488 & 0.0504 \\
\hline Sri Petaling & 0.0324 & 0.2421 & -0.3621 & 0.6252 & 0.9873 & -0.1617 & -0.0905 & 0.2284 \\
\hline Taman Tun Dr Ismail & 0.4451 & 0.1409 & 0.0681 & 0.7094 & 0.6414 & 0.3724 & 0.4493 & 0.5619 \\
\hline Titiwangsa & 0.1721 & 0.0616 & 0.0483 & 0.4083 & 0.3600 & 0.1370 & 0.1664 & 0.1895 \\
\hline Wangsa Maju & 0.2089 & 0.0816 & 0.0330 & 0.4882 & 0.4552 & 0.1609 & 0.1958 & 0.2560 \\
\hline
\end{tabular}

Notes: Goodness of fit: Adjusted $\mathrm{R}^{2}=0.84$. AIC=3017.74 (HPM); AIC=2074.746 (GWR) 


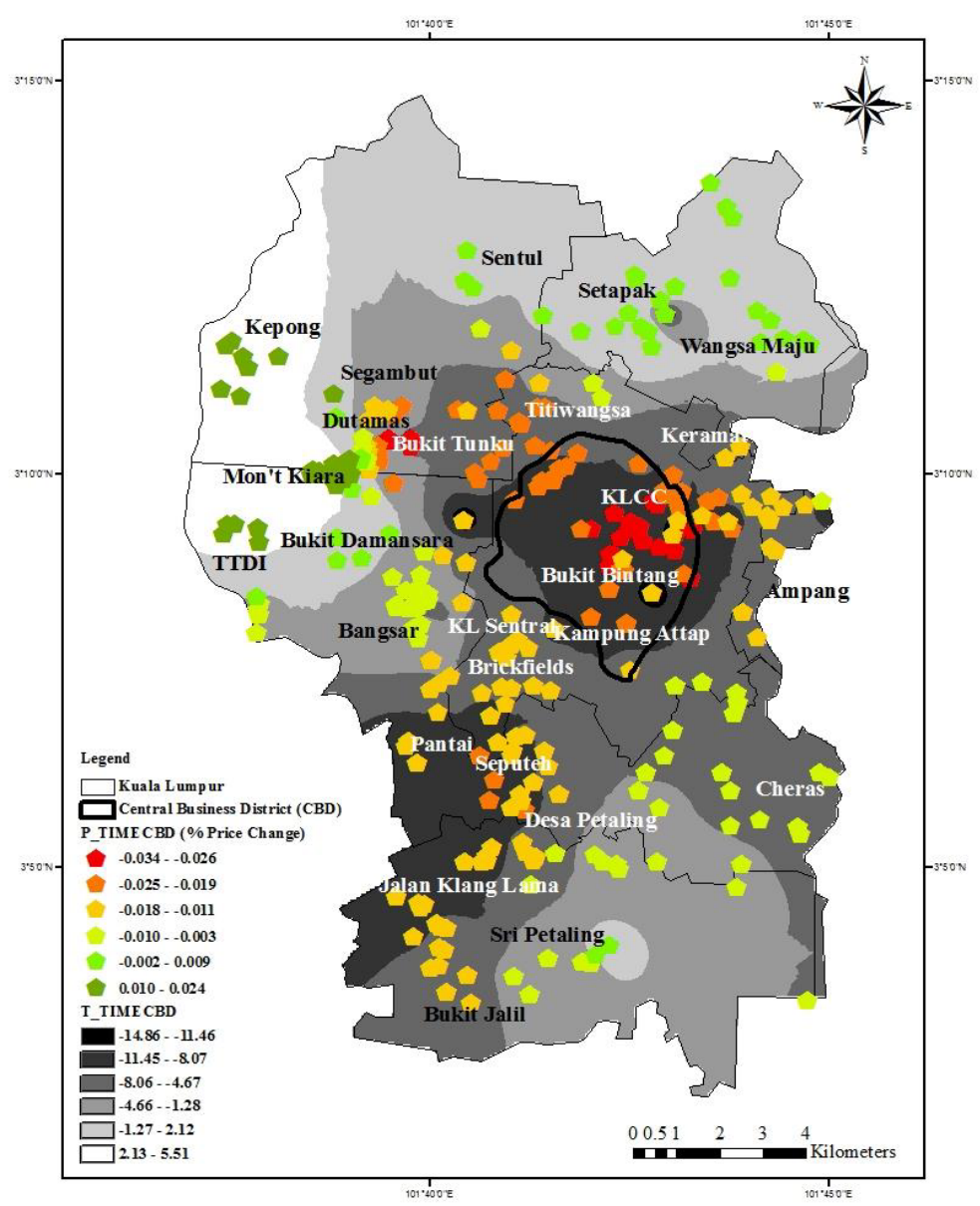

Figure 2: Map of the local estimated coefficients associated with variable TIMECBD Since the focus of this paper is on the impact of accessibility to the CBD on high-rise condominium price gradient, hence only TIMECBD variable is mapped (see Figure 2). In Figure 2 , the background shading refers to the local significance of the estimated coefficients. The values of the local estimated coefficients are shown as different colour points; negative values are coloured of red whilst positive values are coloured of green. It is obvious from the map that the price impact of travel times to the CBD varies considerably over geographical space where the magnitude of impact is found much larger in some areas but less and counterintuitive impact in others. For example, 10 minutes increases in travel times are associated with 10 to 34 per cent (yellow, orange and red dots) declines in sales price as compared to the HPM of 7 per cent, shown in Table 3. Interestingly, the map also shows significant positive local coefficients for condominiums located in Taman Tun Dr. Ismail (TTDI), Mon't Kiara and Kepong housing sub- 
markets (dark green dots) in which 10 minutes increases in travel times to the CBD are associated with 10 to 24 per cent increases in sales price. Using known information about Kuala Lumpur and its surrounding areas, the significant positive coefficient effects with increases of travel times to the CBD in these housing sub-markets can be associated with the emergence of urban sub-centre known as Bandar Utama (lit. Major Urban). This urban sub-centre is an affluent residential township and home for businesses and consumption activities such as commercial areas (IKEA outlet - largest in Southeast Asia, 1 Utama Shopping Mall - one of the biggest in Malaysia, Tesco and the Curve Mall), a five-star hotel and a private college, thus has made the distance to the CBD no longer a significant determinant of land values and subsequently property prices. This is in accordance with the findings of Heikkila et al. (1989) and Waddell et al. (1993) in Los Angeles, USA. Similar patterns were also observed for condominium located in Sentul, Wangsa Maju and Setapak (light green dots). Again, these housing sub-markets are served by new prominent urban sub-centre known as Bandar Wangsa Maju (lit. Wangsa Maju Township).

\section{CONCLUSIONS}

As previously stated, the purpose of this paper was to investigate the impact of accessibility to the $\mathrm{CBD}$ on high-rise condominium price gradient in Kuala Lumpur, Malaysia. More specifically, this paper attempts to identify the monocentric negative price gradient as travel times to the CBD increase. Using a GWR approach, after controlling other factors, this study clearly reveals that the impact of accessibility to the CBD on high-rise condominium prices varies across the study area, having a much larger positive impact in some areas but less and counterintuitive impact in others. In general, the results from this study show accessibility to the CBD measured by the travel times does affect high-rise condominium prices (high-rise condominium price decreases as travel times to the CBD increases) in most part of the areas, hence proved Alonso, Muth and Mills were still right. This suggests that the CBD is still playing a significant factor in influencing land values and subsequently property prices at least in the context of developing countries such as Malaysia. However, the results from the GWR also show that high-rise condominium prices increase as travel times to the CBD increase for condominiums located in Taman Tun Dr. Ismail (TTDI), Mon't Kiara, Kepong, Sentul, Wangsa Maju and Setapak housing sub-markets. This implies that although the CBD proved to be a significant factor in influencing high-rise condominium price in most part of the areas, but its dominance seems to be challenged by the growth of urban sub-centres.

Evidence of this nature is not only important to understand the impact of accessibility to the CBD on high-rise condominium prices, but they also have important implications for public policy. Most obvious is to provide/improve public transports such as bus service or rail transit systems to those areas that are located further away from the CBD in order to increase their accessibility. As widely recognised, areas with a high degree of accessibility to the CBD are 
proven to improve the land values and subsequently property prices such as high-rise condominium prices. For example, research carried out by Dziauddin et al. (2015), Mulley (2014) and Banister (2007) demonstrated that accessibility improvements due to the existence of good public transport are likely to bring premiums in property values. The increase in property values is in turn able to increase government revenues through tax collection.

\section{REFERENCES}

Abu Zharin, H. and Bujang, A. A. (1999), Factors influencing demand for condominium In Johor Bahru, Malaysia. International Real Estate Society 1999 (IRESC '99): Mandarin Oriental, Kuala Lumpur.

Ahlfeldt G. M. and Kavetsos G. (2014), 'Form or function? The impact of new sports stadia on property prices in London'. Journal of the Royal Statistical Society: Series A (Statistics in Society), 177 (1), pp. 169-190.

Ahlfeldt, G. M. and Maennig, W. (2008), 'Impact of sports arenas on land values: Evidence from Berlin'. The Annals of Regional Science, 44 (2), pp. 205-227.

Ahlfeldt, G. M. and Maennig, W. (2010), 'Stadium architecture and urban development from the perspective of urban economics'. International Journal of Urban and Regional Research, 34 (3).

Alonso, W. (1964), Location and Land Use: Towards a General Theory of Land Rent. Cambridge, MA: Harvard University Press.

Anas, A., Arnott, R. and Small, J.A. (1998), 'Urban of spatial structure'. Journal of Economic Literature, 36, pp. 1426- 1464.

Anselin, L. (1988), Spatial Econometrics: Methods and Models. Dordrecht: Kluwer Academic.

Banister, D. (2007), Qualification of the non-transport benefits resulting from rail investment, [online], Available: www.tsu.ox.ac.uk/research/ pubs/1029-banister.pdf.

Bender, B. and Hwang, H. (1985), 'Hedonic housing price indices and secondary employment centers'. Journal of Urban Economics, 17, pp. 90-107.

Brunsdon, C., Fotheringham, A. S., and Charlton, M. (1996), 'Geographically weighted regression: A method for exploring spatial non-statianary'. Geographical Analysis, 28, pp. 281-289.

Calvo, E. and Escolar, M. (2003), The local voter: A geographically weighted approach to ecological inference. American Journal of Political Science, 47 (1), pp. 189-204.

Carruthers, J. I. and Clark, D. (2009), 'Valuing environmental quality: A space-based strategy'. Journal of Regional Science.

Chin, T. L. and Chau, K. W. (2003), A critical review of literature on the hedonic price model'. International Journal for Housing Science and Its Applications, 27 (2), pp. 145-165.

Clapp, J. M. and Giaccotto, C. (1998), Residential hedonic models: A rational expectations approach to age effects'. Journal of Urban Economics, 44, pp. 415-437. 
Conroy, S. J. dan Milosch, J. L. (2011), 'An estimation of the coastal premium for residential housing prices in San Diego County'. The Journal of Real Estate Finance and Economics. 42, pp. 211-228.

Conroy, S., Narwold, A, and Sandy J. (2013), 'The value of a floor: valuing floor level in high rise condominiums in San Diego'. International Journal of Housing Markets and Analysis, 6 (2), pp. 197-208.

Crespo, R. and Grêt-Regamey, A. (2013), 'Local hedonic house-price modelling for urban planners: advantages of using local regression techniques'. Environment and Planning B: Planning and Design. 40 (4), pp. 664 - 682.

Crompton, J. L. (2001), 'The impact of parks on property values: A review of empirical evidence'. Journal of Leisure Research, 33 (1), pp. 1-31.

D’Ouville, E. L. and McDonald, J. F. (1988), 'Constraints on land consumption and urban rent gradients'. Journal of Urban Economics, 24.

Day, B., Bateman, I. and Lake, I. (2007), 'Beyond implicit prices: recovering theoretically consistent and transferable values for noise avoidance from a hedonic property price model'. Environ Resource Econ, 37, pp. 211-232.

Department of Statistics Malaysia (1980), The Malaysia Population and Housing Census. Kuala Lumpur: Department of Statistics Malaysia.

Department of Statistics Malaysia (2010), The Malaysia Population and Housing Census. Kuala Lumpur: Department of Statistics Malaysia.

Do, A.Q. and Grunditski, G. (1995), 'Golf-course and residential house prices: An empirical examination'. Journal of Real Estate Finance and Economics, 10 (3), pp. 261-270.

$\mathrm{Du}, \mathrm{H}$. and Mulley, C. (2006), 'Relationship between transport accessibility and land value: Local model approach with geographically weighted regression'. Transportation Research Record, 1977 (1), pp. 197-205.

Dubin, R. A. dan Sung, C. H. (1990), 'Specification of hedonic regressions: Non-nested tests on measures of neighborhood quality'. Journal of Urban Economics, 27, pp. 97-110.

Dziauddin, M. F., Powe, N. and Alvanides, S. (2015), Estimating the effects of light rail transit (LRT) system on residential property values using geographically weighted regression (GWR). Applied Spatial Analysis and Policy, 8, pp. 1-25.

Fletcher, M., Gallimore, P. and Mangan, J. (2000), 'Heteroscedasticity in hedonic price models'. Journal of Property Research, 17 (2), pp. 93-108.

Forrest, D., Glen, J., Grime, J. and Ward, R. (1996), 'House price changes in greater Manchester 1990-1993 and the impact of metro link'. Journal of Transport Economics and Policy, 30 (1), pp. 15-29.

Fotheringham, A. S., Brunsdon, C. and Charlton, M. (2002), Geographically weighted regression: The analysis of spatially varying relationships. England: John Wiley \& Sons Ltd. 
Fujita, M. (1989), Urban economic theory: Land use and city size. Cambridge: Cambride University Press.

Garreau, J. (1991), Edge City. New York: Dounleday.

Gibbons, S. (2014), Gone with the wind: Valuing the visual impact of the wind turbines through house prices. Serc paper discussion: London School of Economics and Political Sciences \& Spatial Economics Research Centre.

Gibbons, S. and Machin, S. (2003), 'Valuing English primary schools'. Journal of Urban Economics, 53, pp. 197-219.

Hanham, R. M., Hoch, R. J. and Spiker J. S. (2009), The Spatially Varying Relationship Between Local Land-Use Policies And Urban Growth: A Geographically Weighted Regression. In: Gatrell, J. D. and Jensen, R. R. (eds.), Planning and Sosioeconomic Applications. Netherlands: Springer Netherlands, pp. 43-56.

Hess, D. B. and Almeida, T. M. (2006), Impact of proximity to light rail rapid transit on stationarea property values in Buffalo. Transportation research board 85th Annual Meeting: National Research Council, Washinton DC.

Hess, D. B. and Almeida, T. M. (2007), 'Impact of proximity to light rail rapid transit on stationarea property values in Buffalo, New York'. Urban Studies, 44 (5-6), pp. 1041-1068.

Jim, C.Y. and Chen, W.Y. (2009), 'Value of scenic views: Hedonic assessment of private housing in Hong Kong'. Journal of Landscape and Urban Planning, pp. 1-9.

Jones, K. and Bullen, N. (1993), 'A multilevel analysis of the variations in domestic property prices: Southern England 1980-1987'. Urban Studies, 30 (8), pp. 1409- 1426.

Lansford, N. H, and Jones, L. L. (1995), 'Recreational and aesthetic value of water using hedonic price analysis'. Journal of Agricultural and Resource Economics, 20 (2), pp. 341-355.

Lazrak, F., Nijkamp, P., Rietveld, P. and Rouwendal, J. (2014). 'The market value of cultural heritage in urban areas: An application of spatial hedonic pricing'. Journal of Geographical Systems, 16, pp. 89-114.

Lehner M. (2011), Modelling House Prices in Singapore Applying Hedonic Spatial Regression. Master Thesis (unpublished), Swiss Federal Institute of Technology Zurich.

Luo, J. and Wei, Y.H.D. (2009), 'Modeling spatial variations of urban growth patterns in Chinese cities: The case of Nanjing'. Landscape and Urban Planning. 91 (2), pp. 51-64.

Malpezzi, S. (2002), Hedonic Pricing Models and House Price Indexes: A Select Review. In Kenneth Gibb and Anthony O'Sullivan (eds.), Housing Economics and Public Policy: Essays in Honour of Duncan Maclennan. Oxford: Blackwell Publishing, pp. 67-89.

McCord, M., Davis, P.T., Haran, M., McGreal, S. and Mcllhatton, D. (2012), 'Spatial variation as a determinant of house price: Incorporating a geographically weighted regression approach within the Belfast housing market'. Journal of Financial Management of Property and Construction, 17 (1), pp. 49-72.

McDonald, J.F. (1979), Economic Analysis of an Urban Housing Market Studies in Urban Economics. Academic Press. 
McMullen, B. A. (2011), The Economic Impacts of Parks on Residential Property Values: Evidence from Gainesville, Florida. Master Thesis (unpublished), University of Florida.

Mills, E. and Simenauer, R. (1996), 'New hedonic estimates of regional constant quality house prices'. Journal of Urban Economics, 39, pp. 209-15.

Mills, E. S. (1972), Urban Economics. Illinois: Scott, Foresman and Company.

Mitchell, D. (2000), Cultural Geography: A Critical Introduction. Oxford: Blackwell.

Mohamad, J. and Kiggundu, A.T. (2007), 'The rise of the private car in Kuala Lumpur: Assessing the policy option'. IATSS Research, 31 (1), pp. 69-77.

Mohd Shariff, N. and Rainis, R. (2009), Modelling Urban Spatial Structure using Geographically Weighted Regression. 18th World IMACS congress and MODSIM09 international congress on modelling and simulation: The Australian National University.

Mok, H.M.K., Chan, P.P.K. and Cho, Y.S. (1995), 'A hedonic price model for private properties in Hong Kong', Journal of Real Estate Finance \& Economics, 10, pp. 37-48.

Mulley, C. (2014), 'Accessibility and residential land value uplift: Identifying spatial variations in the accessibility impacts of a bus transitway', Urban Studies, 51 (8), pp. 1707-24.

Muth, R. F. (1969). Cities and housing: The Spatial Pattern of Urban Residential Land Use. Chicago: The University of Chicago Press.

Nakaya, T., Fotheringham, A. S., Charlton, M. and Brunsdon, C. (2009), Semiparametric geographically weighted generalised linear modelling in GWR 4.0. In Lees, B. and Laffan, S. (eds.), 10th International Conference on GeoComputation: UNSW Sydney, Australia.

Orford, S. (1999). Valuing The Built Environment: GIS and House Price Analysis. England: Ashgate Publishing Ltd.

Powe, N.A., Garrod, D. Willis, K.G. (1995), 'Valuation of urban amenities using an hedonic price model'. Journal of Property Research, 12, pp. 137-147.

Powe, N.A., Garrod, G.D., Brunsdon, C.F. and Willis, K.G. (1997), 'Using a geographic information system to estimate an hedonic price model of the benefits of woodland access'. Forestry, 70 (2), pp. 139-149.

Richardson, H.W., Vipond, J. and Furbey, R.A. (1974), 'Determinants of urban house prices'. Urban Studies, 11, pp. 189-199.

Rosen, S. (1974), 'Hedonic prices and implicit markets: Product differentiation in pure competitions'. Journal of Political Economy, 72, pp. 34-55.

Sirmans, G. S., and Macpherson, D. (2003), 'The State of affordable housing'. Journal of Real Estate Literature, 11 (2), 131-156.

Sunak, Y. and Madlener, R. (2012), The Impact of Wind Farms on Property Values: A Geographically Weighted Hedonic Pricing Model. FCN Working Paper No. 3/2012 (revised March 2013).

Theebe, M. A. J. (2004), 'Palnes, trains and automobiles: The impact of traffic noise on house prices'. Journal of Real Estate Finance and Economics. 28 (2/3), pp. 209-234. 
Tu, C.C. (2005), 'How does a new sports stadium affect housing values? The case of FedEx field'. Land Economics, 81 (3), pp. 379-395.

Tyrvainen, L. (1997), 'The amenity value of the urban forest: An application of the hedonic pricing method'. Landscape and Urban Planning, 37 (3), pp. 211-222.

Vandegrift, D. and Lahr, M. (2011), 'Open space, house prices, and the tax base'. The Annals of Regional Science, 46 (1), pp 83-100.

Wang, K., Chan S. H. and Yang, J. (2011). 'A rational explanation for boom-and-bust price patterns in real estate markets'. International Real Estate Review, 14 (3), pp. 257-282.

Wang, K., Erikson, J. and Chan, S.H. (1995), 'Does the REIT stock market resemble the general stock market?'. Journal of Real Estate Research, 10 (4), pp. 445-460.

Wilhelmsson, M. (2000). 'The impact of traffic noise on the values of single-family houses'. Journal of Environmental Planning and Management. 43 (6): pp. 799-815.

Yearbook Statistics of Malaysia (1984), Department of Statistics: Kuala Lumpur.

Yearbook Statistics of Malaysia (2010), Department of Statistics: Kuala Lumpur. 